\title{
Multy-stressor Analysis of Sociocultural Condition: A Study on Land Degradation in Kreo Watershed, Semarang City
}

\author{
Juhadi $^{1}$, Elok Surya Pratiwi ${ }^{2}$, Edy Trihatmoko $^{3}$, Nur Laily Muyassaroh ${ }^{4}$ \\ \{juhadigeo@mail.unnes.ac.id ${ }^{1}$, eloksurya@mail.ac.id ${ }^{2}$, edytrihatmoko@gmail.com ${ }^{3}$, \\ lailymusyassaroh@gmail.com ${ }^{4}$ \} \\ ${ }^{1,2,3}$ Universitas Negeri Semarang, Indonesia ${ }^{1}$ \\ Universitas Gadjah Mada, Indonesia ${ }^{4}$
}

\begin{abstract}
This study aims to examine the multi-stressor of socio-cultural conditions that influencing land degradation in Kreo watershed, Semarang City. Kreo watershed was chosen as the research area due to its complexity that travers Semarang City, the capital city of Central Java Province, Indonesia. This study was conducted by terrestrial surveys with the combination of landform units and farm households as the unit of analysis. The research variables consisted of local institutions, local traditions, social networks, perceptions, attitudes, motivations, and preferences of farmers. The research sample was obtained proportionally and randomly in each landform unit. Quantitative and qualitative approaches were used with emphasising on descriptive and Crosstab analysis. The results showed that several socio-cultural factors inducing to land degradation in Kreo Watershed. This condition put socio-cultural factors as multi-stressor in Kreo watershed. The most dominant factor that effecting land degradation is the low level of people perception of land resources awareness in addressing land degradation.
\end{abstract}

Keywords: Kreo Watershed, Land Degradation, Multi Stressor, Socio-Culture

\section{Introduction}

Land is a physical environment that includes land, climate, relief, hydrology and vegetation which influence the potential for its use. It also includes the consequences of human activities, both in the past and present [1], [2]. Land use is a form of human intervention in using land to fulfill their life needs, both material and spiritual [3]. The example of human interference in manipulating ecological conditions or processes taking place in an area is the conversion of protected forest areas into seasonal agricultural areas and / or secondary crops because they are considered more profitable.

The use of land resources by farmers, anywhere and anytime, will in essence be influenced by the socio-cultural characteristics of the community (Tohir [4]). The relationship between humans and their natural environment is not merely manifested as a relationship of human dependence on their environment, but also manifested as a relationship where humans influence and change their environment (Suparlan et al., 1980). In other words, humans also create patterns and forms of the environment both really and not really (as they imagined) [5]. Culture is a complex whole that contains knowledge, beliefs, arts, morals, and habits that humans acquire as members of society. Humans adapt, integrate and utilize the surrounding environment and use culture. Humans create culture and with that culture they continue and 
improve their standard of living both as an individual and as a member of society (Pelly dan Menanti, 1994:42).

The socio-cultural characteristics of society by Auburn and Nimkof in Tohir (1983) can be determined by many factors including (1) the natural environment; (2) social heritage, life views, customs and institutions inherited from the past; (3) herity (community), community life (the group), the position and views about the economy, the nature and character of the community

For farmers, the influence of socio cultural factors on the aspects of cultural life is very big (Tohar [4]). Humans who continue to strive for their land productivity must maintain the environment. Human should remember that the higher the damage to land, the higher the damage to the existing social and cultural conditions of the community

The dynamics of the utilization of the Kreo watershed is currently growing rapidly, especially in the upstream region. The construction of the Jatibarang reservoir in Kreo watershed increases the acceleration of land cover from vegetation cover to built-up land. Land accessibility and change have also increased

Spatial analysis of land use in 2006-2013 showed a development trend in the construction of residential areas, namely from $9.31 \%$ to $10.08 \%$, whereas the moorland area increased from $4.55 \%$ to $12.58 \%$. According to the Regional Spatial Plan, the upstream area is a conservation area that is cultivated for perennials. But along with the development of the population, there was a development of settlements in the upstream area [1].

This study examines land degradation due to the influence of multi-stressor of sociocultural conditions in the Kreo Watershed in Semarang City. The socio-cultural conditions referred to in this study refer to the concept developed by Juhadi [6], namely a condition related to community life and social interaction, which is formed from local institutions, local traditions, social networks, perceptions, attitudes, motivations and community preferences, and the like.

The purpose of this study is to (1) know the socio-cultural conditions of the people in the Kreo watershed; (2) know the effect of multi-stressor of socio-cultural conditions on land degradation; (3) know the dominant socio-cultural factors affecting land degradation in the Kreo Watershed in Semarang City. This study is expected to provide information for government in making decisions or policies to overcome land degradation, and can provide learning for the community to apply appropriate conservation patterns in each land use.

\section{Research Method}

This research was conducted by survey method, with a unit of analysis of landform units and farm households. The research variables consisted of local institutions, local traditions, social networks, perceptions, attitudes, motivations and preferences of farmers. Farm households and landform units are used as units of research analysis. The research samples were obtained proportionally and randomly in each unit of land. Quantitative and qualitative approaches were used in this study, the nature of the description is descriptive and analyzed using cross tab.

The use of farm household samples is determined by the overlapping results of landform units map and village administration map. The sample size is determined by the size of sampling formula with the percentage of acceptable subjectivity errors which is equal to $0.65 \%$, considering the nature of the farm household population which is more dynamic compared to the relatively static geobiophysical properties of the land [6]. The population of 
farmer households in this study was obtained from the results of the census carried out by the researcher on residents living and scattered in landform units in the study area. The proportional random sampling technique is $25 \%$. Research is supported by data from respondents and informants from community leaders and a number of officials from related agencies.

The measurement of socio-cultural parameters is done by scoring on each indicator using the "Likert scale" with 5 levels $(1,2,3,4$, and 5). Data was collected by asking questions directly to respondents. Respondents were asked to provide explanations through discussion during the interview process (semi qualitative). Then, from the results of the interview, the researcher concluded each item of the respondent's answer by giving a score between 1 to 5 . The answer score 1 means a negative tendency (not good). Conversely, the answer score 5 shows a positive tendency (very good).

\section{Result and Discussion}

\subsection{Socio Cultural Condition of The Community in The Kreo Watershed}

Utilization of agricultural land in the Kreo watershed cannot be separated from the role of socio-cultural factors of the local community. Land use is human actions or expressions in modifying or changing land cover. In other words, the pattern of land use is a reflection of human activities that are on it. Land use is the most vulnerable factor and is always the main target of the effects of change by humans compared to other factors, such as climate, soil, and topography [6].

The type of land use as a result of the influence of multi-stressor of socio-cultural conditions of a community will greatly influence the dynamics of area changes, upper vegetation and lower vegetation density, which ultimately affects land degradation due to erosion [6]. In the upper Kreo watershed, efforts to keep farmland covered by vegetation have been done by local people from generation to generation and become a positive habit in every land use in the forms of mixed garden (Figure 1). This is different from the condition in the downstream Kreo watershed in which land use types are dominated by settlements and industrial estates.

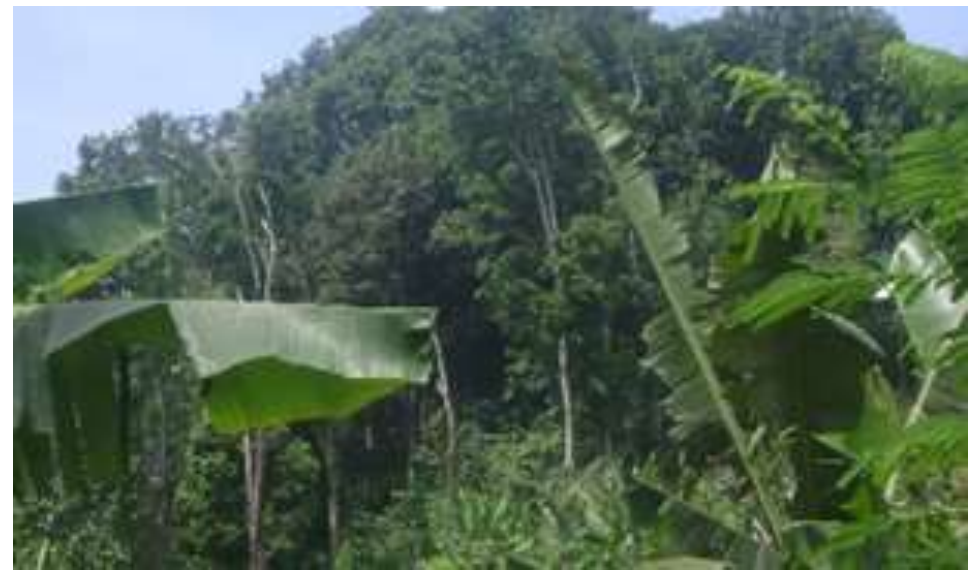

Figure 1. Mixed Garden in The Upper Kreo Watershed

People in the upper Kreo watershed make a living as traditional farmers. Land use in the 
central region of the Kreo watershed is in the form of the cultivation of perennials such as fruits, orchids, and the construction of small dam "mini embung" to store rainwater in the rainy season to anticipate water shortages in the dry season as showed in Figure 2. The activity of planting fruits and orchids is expected by the local community to reduce the felling rate of trees by the community, because these plants have relatively high economic value, and can be utilized for a relatively long period of time.

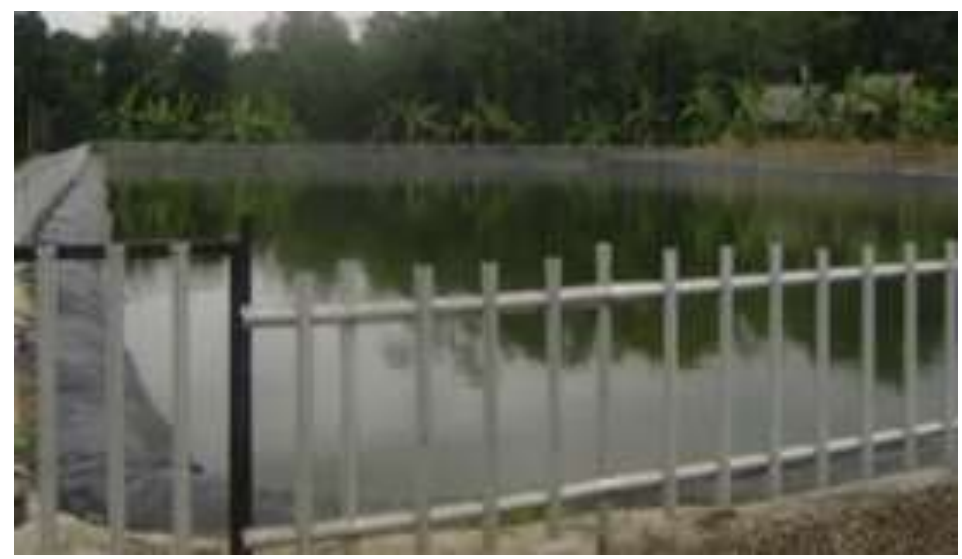

Figure 2. Mini Embung in Bubakan Village, Mijen Sub-district

\subsection{The Influence of Multi-stressor of Socio-Cultural Condition on Land degradation in The Kreo Watershed}

The results of the study of the effect of multi-stressor of socio-cultural conditions on the level of land degradation in the study area are described in Table 1. Of the 32 units of landform studied, there are three socio-cultural aspects which have a significant influence on land degradation, namely aspects of local institutions. perceptions, and preferences of the community.

Table 1. Multi-stressor of Socio Cultural Condition Affecting Land degradation in the Kreo

\begin{tabular}{|c|c|c|c|c|c|c|c|c|}
\hline Landforms & $\begin{array}{l}\text { Unit } \\
\text { Code } \\
\text { BL }\end{array}$ & $\begin{array}{l}\text { Local } \\
\text { Instituti } \\
\text { on }\end{array}$ & $\begin{array}{l}\text { Local } \\
\text { Traditi } \\
\text { on }\end{array}$ & $\begin{array}{l}\text { Social } \\
\text { Network } \\
\end{array}$ & $\begin{array}{l}\text { Community } \\
\text { Perception }\end{array}$ & Attitude & $\begin{array}{l}\text { Motivat } \\
\text { ion }\end{array}$ & $\begin{array}{l}\text { Prefe } \\
\text { rence }\end{array}$ \\
\hline $\begin{array}{l}\text { Volcanic High Hills, results } \\
\text { of the young quarter } \\
\text { volcano }\end{array}$ & $\begin{array}{l}\text { IIII5V } \\
\text { b }\end{array}$ & 50,00 & 9,62 & 38,46 & 67,31 & 42,31 & 32,69 & 43,08 \\
\hline $\begin{array}{l}\text { Volcanic High Hills, results } \\
\text { of the old quarter volcano }\end{array}$ & $\begin{array}{l}\text { III6V } \\
\text { b }\end{array}$ & 45,83 & 10,42 & 31,25 & 66,67 & 33,33 & 25,00 & 34,58 \\
\hline $\begin{array}{l}\text { Volcanic High Mountains, } \\
\text { results of the young quarter } \\
\text { volcano }\end{array}$ & $\begin{array}{l}\text { IV } 5 \mathrm{~V} \\
\mathrm{a}\end{array}$ & 16,67 & 8,33 & 58,33 & 8,33 & 8,33 & 8,33 & 36,67 \\
\hline $\begin{array}{l}\text { Volcanic High Hills, results } \\
\text { of the young quarter } \\
\text { volcano }\end{array}$ & $\begin{array}{l}\text { IV5V } \\
\mathrm{b}\end{array}$ & 45,45 & 2,27 & 38,64 & 52,27 & 22,73 & 15,91 & 37,27 \\
\hline $\begin{array}{l}\text { Volcanic High Hills, results } \\
\text { of the old quarter volcano }\end{array}$ & $\begin{array}{l}\text { IV6V } \\
\text { b }\end{array}$ & 46,67 & 11,67 & 31,67 & 2,86 & 31,67 & 23,33 & 33,00 \\
\hline
\end{tabular}




\begin{tabular}{|c|c|c|c|c|c|c|c|c|}
\hline Landforms & $\begin{array}{l}\text { Unit } \\
\text { Code } \\
\text { BL } \\
\end{array}$ & $\begin{array}{l}\text { Local } \\
\text { Instituti } \\
\text { on }\end{array}$ & $\begin{array}{l}\text { Local } \\
\text { Traditi } \\
\text { on }\end{array}$ & $\begin{array}{l}\text { Social } \\
\text { Network }\end{array}$ & $\begin{array}{l}\text { Community } \\
\text { Perception }\end{array}$ & Attitude & $\begin{array}{l}\text { Motivat } \\
\text { ion }\end{array}$ & $\begin{array}{l}\text { Prefe } \\
\text { rence }\end{array}$ \\
\hline $\begin{array}{l}\text { Denudational Hills, results } \\
\text { of the young quarter } \\
\text { volcano }\end{array}$ & I5Dc & 53,13 & 10,94 & 26,56 & 71,88 & 32,81 & 21,88 & 46,88 \\
\hline $\begin{array}{l}\text { Denudational Hills, results } \\
\text { of the old quarter volcano }\end{array}$ & II6Dc & 50,00 & 21,88 & 31,25 & 3,53 & 43,75 & 28,13 & 41,25 \\
\hline $\begin{array}{l}\text { Denudational Hills, results } \\
\text { of the young quarter } \\
\text { volcano }\end{array}$ & II5Dc & 50,00 & 41,67 & 33,33 & 3,48 & 50,00 & 41,67 & 48,33 \\
\hline $\begin{array}{l}\text { Denudational Hills, results } \\
\text { of the young quarter } \\
\text { volcano }\end{array}$ & $\begin{array}{l}\text { III5D } \\
\mathrm{b}\end{array}$ & 37,50 & 0,00 & 18,75 & 50,00 & 12,50 & 12,50 & 40,00 \\
\hline $\begin{array}{l}\text { Sedimentary Facies } \\
\text { Pleistocene Denudational } \\
\text { Hills }\end{array}$ & I2Dc & 70,00 & 10,00 & 25,00 & 80,00 & 30,00 & 25,00 & 56,00 \\
\hline $\begin{array}{l}\text { Alluvium Denudational } \\
\text { Hills }\end{array}$ & $\mathrm{I} 3 \mathrm{Dc}$ & 60,00 & 10,00 & 30,00 & 80,00 & 25,00 & 20,00 & 55,00 \\
\hline $\begin{array}{l}\text { Volcano Facies Pleistocene } \\
\text { Denudational Hills }\end{array}$ & I4Dc & 65,38 & 9,62 & 30,77 & 65,38 & 34,62 & 26,92 & 50,77 \\
\hline $\begin{array}{l}\text { Alluvium Denudational } \\
\text { Low Hills }\end{array}$ & $\begin{array}{l}\text { III3D } \\
\mathrm{d}\end{array}$ & 59,09 & 18,18 & 31,82 & 79,55 & 34,09 & 25,00 & 62,73 \\
\hline $\begin{array}{l}\text { Alluvium Denudational } \\
\text { Low Hills }\end{array}$ & I3Dd & 75,00 & 37,50 & 37,50 & 87,50 & 37,50 & 25,00 & 75,00 \\
\hline $\begin{array}{l}\text { Alluvium Denudational } \\
\text { Inland Low Hills }\end{array}$ & $\begin{array}{l}\text { III5V } \\
\mathrm{b}\end{array}$ & 75,00 & 37,50 & 37,50 & 87,50 & 37,50 & 25,00 & 60,00 \\
\hline $\begin{array}{l}\text { Sedimentary Facies } \\
\text { Pleistocene Fluvial Hills }\end{array}$ & $\mathrm{I} 2 \mathrm{Fc}$ & 75,00 & 16,67 & 16,67 & 66,67 & 50,00 & 50,00 & 53,33 \\
\hline Alluvium Fluvial Hills & $\mathrm{I} 3 \mathrm{Fc}$ & 68,75 & 12,05 & 18,75 & 68,75 & 31,25 & 18,75 & 58,75 \\
\hline $\begin{array}{l}\text { Volcano Facies Pleistocene } \\
\text { Fluvial Hills }\end{array}$ & $\mathrm{I} 4 \mathrm{Fc}$ & 68,18 & 15,91 & 27,27 & 61,36 & 31,82 & 27,27 & 49,55 \\
\hline $\begin{array}{l}\text { Fluvial Hills, results of the } \\
\text { young quarter volcano }\end{array}$ & $\mathrm{I} 5 \mathrm{Fc}$ & 50,00 & 22,73 & 31,82 & 70,45 & 34,09 & 25,00 & 56,36 \\
\hline $\begin{array}{l}\text { Alluvium Fluvial Inland } \\
\text { Lowland }\end{array}$ & III3Ff & 59,62 & 21,15 & 30,77 & 71,15 & 28,85 & 21,15 & 52,50 \\
\hline $\begin{array}{l}\text { Sedimentary Facies } \\
\text { Pleistocene Fluvial Hills }\end{array}$ & $\begin{array}{l}\mathrm{III} 2 \mathrm{~F} \\
\mathrm{c}\end{array}$ & 75,00 & 16,67 & 16,67 & 66,67 & 50,00 & 50,00 & 58,33 \\
\hline $\begin{array}{l}\text { Sedimentary Facies } \\
\text { Pleistocene Fluvial Low } \\
\text { Hills }\end{array}$ & $\begin{array}{l}\text { III } 2 \mathrm{~F} \\
\mathrm{~d}\end{array}$ & 60,00 & 25,00 & 35,00 & 65,00 & 30,00 & 20,00 & 57,00 \\
\hline Alluvium Fluvial Low Hills & $\begin{array}{l}\text { III } 3 F \\
d\end{array}$ & 62,50 & 25,00 & 20,83 & 85,00 & 29,17 & 20,83 & 61,67 \\
\hline $\begin{array}{l}\text { Fluvial Hills, results of the } \\
\text { young quarter volcano }\end{array}$ & II5Fc & 47,50 & 20,00 & 32,50 & 85,71 & 42,50 & 27,50 & 1,87 \\
\hline $\begin{array}{l}\text { Fluvial Hills, results of the } \\
\text { old quarter volcano }\end{array}$ & II6Fc & 42,86 & 14,29 & 25,00 & 75,00 & 46,43 & 28,57 & 45,00 \\
\hline $\begin{array}{l}\text { Fluvial Hills, results of the } \\
\text { young quarter volcano }\end{array}$ & $\mathrm{II} 5 \mathrm{Fb}$ & 50,00 & 14,29 & 39,29 & 75,00 & 46,43 & 32,14 & 41,43 \\
\hline
\end{tabular}




\begin{tabular}{|c|c|c|c|c|c|c|c|c|}
\hline Landforms & $\begin{array}{l}\text { Unit } \\
\text { Code } \\
\text { BL } \\
\end{array}$ & $\begin{array}{l}\text { Local } \\
\text { Instituti } \\
\text { on } \\
\end{array}$ & $\begin{array}{l}\text { Local } \\
\text { Traditi } \\
\text { on } \\
\end{array}$ & $\begin{array}{l}\text { Social } \\
\text { Network } \\
\end{array}$ & $\begin{array}{l}\text { Community } \\
\text { Perception }\end{array}$ & Attitude & $\begin{array}{l}\text { Motivat } \\
\text { ion }\end{array}$ & $\begin{array}{l}\text { Prefe } \\
\text { rence }\end{array}$ \\
\hline $\begin{array}{l}\text { Fluvial Hills, results of the } \\
\text { young quarter volcano }\end{array}$ & $\begin{array}{l}\text { III5F } \\
\mathrm{c}\end{array}$ & 50,00 & 50,00 & 50,00 & 90,00 & 62,50 & 50,00 & 52,50 \\
\hline $\begin{array}{l}\text { Fluvial Hills, results of the } \\
\text { old quarter volcano }\end{array}$ & $\begin{array}{l}\text { III6F } \\
\mathrm{c}\end{array}$ & 50,00 & 25,00 & 35,00 & 65,91 & 55,00 & 35,00 & 52,00 \\
\hline $\begin{array}{l}\text { Fluvial Hills, results of the } \\
\text { young quarter volcano }\end{array}$ & $\begin{array}{l}\text { III5F } \\
\mathrm{b}\end{array}$ & 50,00 & 11,36 & 34,09 & 66,67 & 34,09 & 25,00 & 35,00 \\
\hline $\begin{array}{l}\text { Fluvial Hills, results of the } \\
\text { old quarter volcano }\end{array}$ & $\begin{array}{l}\text { III6F } \\
b\end{array}$ & 45,83 & 10,42 & 31,25 & 37,50 & 33,33 & 25,00 & 30,00 \\
\hline $\begin{array}{l}\text { Fluvial Hills, results of the } \\
\text { young quarter volcano }\end{array}$ & $\begin{array}{l}\text { IV5F } \\
\mathrm{b}\end{array}$ & 37,50 & 12,50 & 62,50 & 59,09 & 12,50 & 12,50 & 32,50 \\
\hline $\begin{array}{l}\text { Fluvial Hills, results of the } \\
\text { old quarter volcano }\end{array}$ & $\begin{array}{l}\text { IV6F } \\
b\end{array}$ & 40,91 & 11,36 & 34,09 & 59,09 & 29,55 & 20,45 & 33,18 \\
\hline & & 54,60 & 17,83 & 32,52 & 61,81 & 35,29 & 26,62 & 47,04 \\
\hline
\end{tabular}

Source : Juhadi and Muyassaroh, 2014

Table 1 illustrates that the level of land degradation as a result of the multi-stressor of socio-cultural conditions of the local community varies in each landform unit. The sociocultural aspects having relatively high influences on land degradation in the research area, are local institutions, community perceptions and people's preferences. While other socio-cultural aspects such as community attitudes and social networks have relatively small influences.

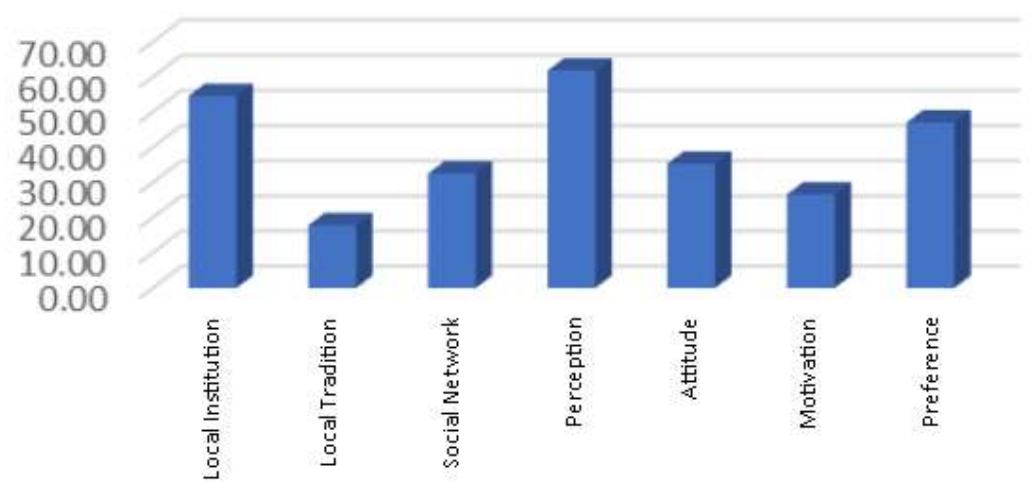

Figure 3. Level of Influence of Multi-stressor of Socio-Cultural Condition on Land degradation

Research results showed that there was an influence on farmers' decision making towards the formation of land use patterns. The pattern of land use and land degradation in an area is a reflection of human activities in the area that supports it. Changes in land use reflect the dynamic activities of the community so that changes in land use are also faster (Sandy, 1982 [5], [6]). This shows that socio-cultural life can be described through patterns of land use in the area concerned, and at the same time can be used as indicators of the community in treating natural resources. However, the desire of the community to fulfill their needs does not mean that they can sacrifice environmental sustainability. 


\subsection{Dominant Socio-Cultural Factors towards Land degradation in The Kreo Watershed in Semarang City}

The influence of multi-stressor of community socio cultural condition on level of land degradation in the research area is described in Table 2 and Figure 4.

Table 2. Dominant Socio-Cultural Factors towards Land degradation in The Kreo Watershed in Semarang City

\begin{tabular}{|c|c|c|c|c|c|c|c|}
\hline Criteria & $\begin{array}{l}\text { Local } \\
\text { Institutio } \\
\text { n }\end{array}$ & $\begin{array}{l}\text { Local } \\
\text { Traditio } \\
\text { n }\end{array}$ & $\begin{array}{l}\text { Social } \\
\text { Networ } \\
\mathbf{k}\end{array}$ & $\begin{array}{l}\text { Perceptio } \\
\text { n }\end{array}$ & $\begin{array}{l}\text { Attitud } \\
\text { e }\end{array}$ & $\begin{array}{l}\text { Motivatio } \\
\text { n }\end{array}$ & $\begin{array}{l}\text { Preferenc } \\
\text { e }\end{array}$ \\
\hline $\begin{array}{l}\text { Very } \\
\text { High }\end{array}$ & 25,00 & 6,25 & 6,25 & 31,25 & 6,25 & 9,37 & 0,13 \\
\hline High & 21,87 & 6,25 & 0,00 & 56,25 & 28,12 & 6,25 & 18,75 \\
\hline $\begin{array}{l}\text { Moderat } \\
\mathrm{e}\end{array}$ & 43,75 & 18,75 & 18,75 & 6,25 & 37,50 & 0,94 & 28,12 \\
\hline Low & 6,25 & 46,88 & 53,12 & 3,12 & 18,75 & 50,00 & 25,00 \\
\hline $\begin{array}{l}\text { Very } \\
\text { Low }\end{array}$ & 3,12 & 21,88 & 21,87 & 3,12 & 9,37 & 12,50 & 25,00 \\
\hline & 100 & 100 & 100 & 100 & 100 & 100 & 100 \\
\hline
\end{tabular}

Source: Results of Primary Data Analysis, 2014

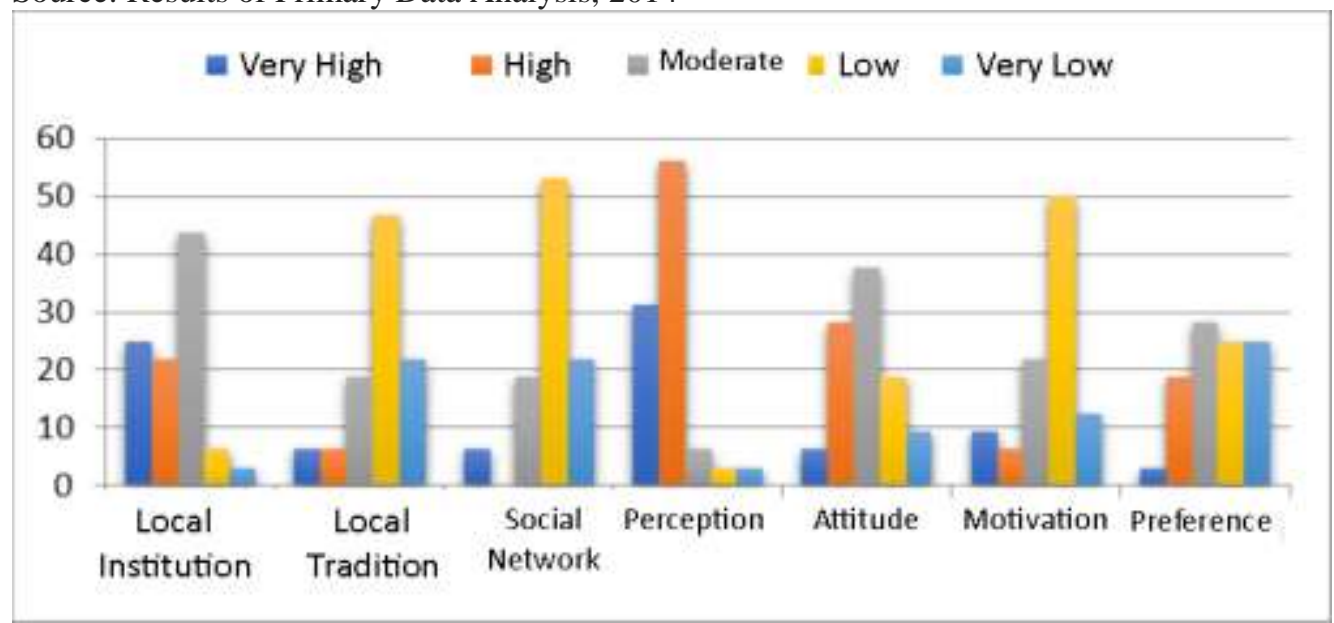

Figure 4. The Influence of Socio-Cultural Condition on Each Aspect

Figure 4 shows the dominant factors influencing land degradation, namely the aspect of community perception (87.5\%), aspects of local institutions in the second rank, which is $46.87 \%$. While the least influence on land degradation is the aspect of social networks $(6.25 \%)$. The influencing scale of land degradation is detailed $\mathrm{n}$ Figure 5. Community perceptions of land especially related to aspects of knowledge and awareness of local communities in the context of land use are generally still low. Efforts to exploit land resources are quite high without thinking about the sustainability of the land resources themselves. One factor that encourages local people to exploit land resources in addition to economic factors, is the limited land ownership, on average less than 1 hectare [4], [7]. 
Basically, the damage to land in the Kreo watershed is a shared responsibility of the community and the government. Therefore, cooperation between the community and the government is needed, especially in the enforcement of regulations regarding the prohibition of illegal mining, the prohibition of opening forests for agriculture and illegal logging carried out by some Kreo watershed communities. So far, law enforcement efforts from the government in the management of land have not taken yet do a concrete action, so that public awareness of environmental issues and especially land is still not growing and developing well.

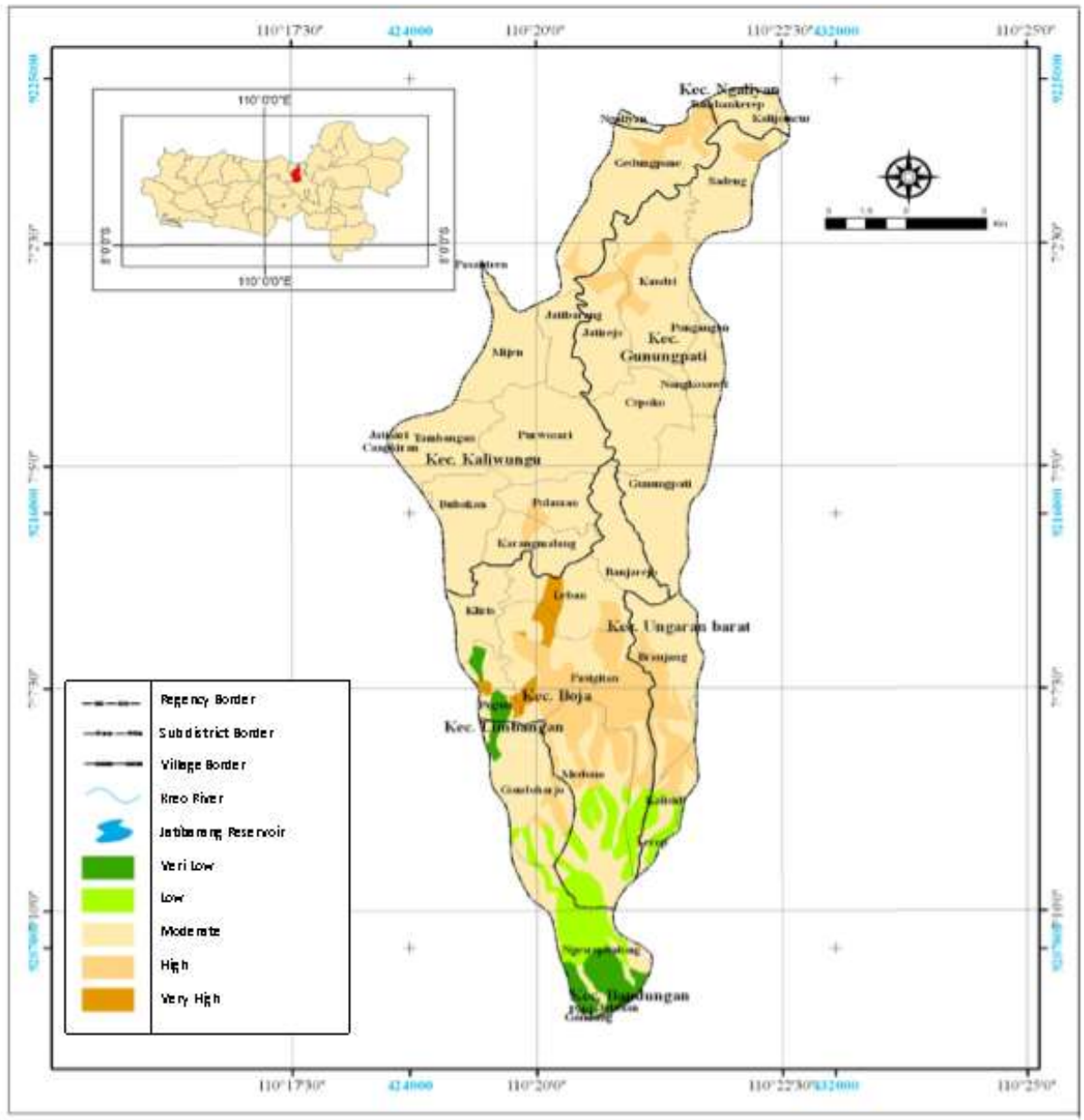

Figure 5. The Influence of Multi-stressor of Socio Cultural Condition on Land degradation in Kreo Watershed, Semarang City 


\section{Conclusion}

There are some conclusions that can be drawn from the results of the research. Most of the people in the upper and middle areas of the Kreo Watershed work as farmers and farm laborers who generally still do simple land processing. However, in the central region of the Kreo Watershed, land processing technologies have begun to develop such as the use of "mini embung" irrigation technology. In the lower reaches of the Kreo watershed, most of the land is allocated to the non-agricultural sector.

The level of land degradation as a result of the multi-stressor of socio-cultural conditions of the local community varies in each landform unit. The socio-cultural aspects have a relatively high influence on land degradation in the research area. Those are community perceptions, local institutions and community preferences. While other socio-cultural aspects such as community attitudes, social networks, and motivations have relatively less effect on land degradation.

\section{Acknowledgement}

The writer would like to thank to the Chief and all members of the committee of ICESI 2019 Faculty of Social Sciences, Universitas Negeri Semarang who have given the writer the chance to participate in the conference. The writer is also grateful for the board of the editor of the proceeding which will publish this article.

\section{References}

[1] J. Juhadi, H. Tjahjono, and R. Arifudin, “Analisis Spasial Tipologi Kerusakan Lahan Berbasis Sistem Informasi Geografis (Spatial Analysis Of Land Damage Typology Based On Geographic Information System),” TATALOKA, vol. 16, no. 4, pp. 209-219, 2014.

[2] S. Ritohardoyo, "Penggunaan dan Tata Guna Lahan," Yogyakarta: Penerbit Ombak, 2013.

[3] A. Arsyad, Media Pembelajaran. Jakarta: PT. RajaGrafindo Permai, 2009.

[4] D. Juhadi, "Dimensi Spasio Ekologikal Pemanfaatan Lahan Perbukitan-Pegunungan Di Kecamatan Kokap, Girimulyo Dan Pengasih Kabupaten Kulonprogo Daerah Istimewa Yogyakarta." Universitas Gadjah Mada, 2013.

[5] Juhadi, "Pola-Pola Pemanfaatan Lahan dan Degradasi Lingkungan pada Kawasan Perbukitan," J. Geogr., vol. 4, no. 1, 2007.

[6] Juhadi, "Model Evaluasi Pemanfaatan Lahan Berkelanjutan Berbasis Multi Dimensional Scalling (MDS) dan Sistem Informasi Geografis (SIG) Kawasan Perbukitan Pegunungan," Lap. Penelitian. Daft. Isisn Pelaks. Anggar., 2013.

[7] C. Geertz, Agricultural involution: the process of ecological change in Indonesia, vol. 11. Univ of California Press, 1963.

\section{Asdak, Chay. 2010. Hidrologi dan Pengelolaan Daerah Aliran Sungai. Yogyakarta: UGM Press.}


